\title{
The Effects of Chronic Gabapentin Administration on the Inflammatory Response in Rats
}

\author{
${ }^{1}$ Bilgin Kaygısız ${ }^{1}$ Fatma Sultan Kılıç \\ ${ }^{1}$ Eskişehir Osmangazi Üniversitesi Tıp Fakültesi, Farmakoloji Anabilim Dalı \\ *email: bilginkay@yahoo.com
}

\begin{abstract}
Besides its approval as an adjunctive anticonvulsant, gabapentin was reported to be effective in neuropathic and inflammatory pain. Antihyperalgesic effect of gabapentin may be related to possible antiinflammatory activity. We aimed to examine the antiinflammatory effect of chronic gabapentin administration on inflammatory response in rats. Experiments were performed with the permission of the Local Ethical Committee of Eskisehir Osmangazi University for the Animal Experimentation (03.03.2011/192). Male Spraque-Dawley rats (200-250g) were randomly divided into control (saline), gabapentin 10,30,100mg/kg and diclofenac $5 \mathrm{mg} / \mathrm{kg}$ groups (n: 8 in each group). $0.1 \mathrm{ml}$ of $2 \%$ formalin solution was injected to the plantar region of the left paw of each rat, on the 1st and 3rd days of the experimental procedure. Drug or saline treatments were started one day after (4th day) the last formalin injection, administered via gavage for 10 days. Paw thickness of the left hind paw was measured on the 1 st day before formalin injection, on the 4th day before the beginning of drug or saline treatments, on the 14th day (one day after the treatment procedure) with a micrometer. The percent edema and edema inhibition was calculated. Results were statistically analysed with Kruskal-Wallis test. All doses of gabapentin and diclofenac decreased \%paw-edema and increased \%edema inhibition compared to control group $(\mathrm{p}<0.05) .30$ and $100 \mathrm{mg} / \mathrm{kg}$ gabapentin decreased $\%$ paw-edema and increased $\%$ edema inhibition compared to diclofenac $(\mathrm{p}<0.05)$ more effectively. We suggest that chronically administered gabapentin may possess antiinflammatory effect which was more than the effect of the reference antiinflammatory drug, diclofenac.
\end{abstract}

KEYWORDS: formalin-induced inflammation, gabapentin, diclofenac, rat

\section{KRONIK GABAPENTIN UYGULAMASININ SIÇANLARDA INFLAMATUVAR YANIT ÜZERINDEKİ ETKİSI}

ÖZET: Gabapentinin antikonvülsan olarak onaylı bir ilaç olmasının yanısıra nöropatik ve inflamatuvar ağrının tedavisinde de etkili olduğu bilinmektedir. Gabapentinin antihiperaljezik etkisi olası bir antiinflamatuvar etkinliğinden kaynaklanabilir. Bu çalışmada kronik gabapentin uygulamasının sıçanlarda inflamatuvar cevap üzerindeki antiinflamatuvar etkisinin araştırılması amaçlanmıştır. Deneyler Eskişehir Osmangazi Üniversitesi Rektörlüğü Hayvan Deneyleri Yerel Etik Kurulu'nun 03.03.2011 tarih ve 192 sayı numaralı kararı ile gerçekleştirilmiştir. Erkek Spraque Dawley sıçanlar (200-250g), her grupta 8 adet olmak üzere randomize olarak kontrol (serum fizyolojik), gabapentin $10,30,100 \mathrm{mg} / \mathrm{kg}$ ve diklofenak $5 \mathrm{mg} / \mathrm{kg}$ gruplarına ayırıldılar. Deney prosedürünün 1. ve 3. günlerinde sıçanların sol arka pençelerinin tabanlarına $0.1 \mathrm{ml} \%$ 2'lik formalin solüsyonu injekte edildi. İlaç tedavileri veya serum fizyolojik uygulaması son formalin uygulamasından 1 gün sonra (4. gün) başlatıldı ve oral yoldan gavajla 10 gün boyunca uygulandı. Pençedeki şişkinlik 1. günde formalin uygulamadan önce, 4. günde ilaç tedavisi başlatılmadan önce ve 14. günde ilaç tedavisi sona erdikten 1 gün sonra mikrometrik kumpas ile ölçüldü. Ödem ve ödem inhibisyonu yüzdesi hesapland. Sonuçlar istatistiksel olarak Kruskal-Wallis testi ile analiz edildi. Gabapentinin tüm dozları ve diklofenak kontrol grubuna göre ödem yüzdesini anlamlı olarak azaltırken ödem inhibisyon yüzdesini anlamlı olarak artırdı $(p<0,05)$. Gabapentin 30 ve $100 \mathrm{mg} / \mathrm{kg}$ dozlarında diklofenak grubuna göre ödem yüzdesindeki azalma ve ödem 
inhibisyonu yüzdesindeki artış daha fazla olarak bulundu $(\mathrm{p}<0,05)$. Bu çalışmanın sonuçlarına göre kronik olarak uygulanan gabapentinin antiinflamatuvar etkisinin olabileceği ve bu etkinin referans bir antiinflamatuvar ilaç olan diklofenaktan daha fazla olduğu ileri sürülebilir.

ANAHTAR KELIMELER: formalinle oluşturulan inflamasyon, gabapentin, diklofenak, sıçan

\section{Introduction}

Gabapentin is a 3-alkylated analog of the neurotransmitter $\gamma$-aminobutyric acid which interacts with an $\alpha_{2} \delta$ subunit of a voltage dependent $\mathrm{Ca}^{2+}$ channel $(1,2)$. At first, gabapentin was approved as an adjunctive anticonvulsant agent. Afterwards, it was approved for the treatment of postherpetic neuralgia (3). In addition, gabapentin has been shown to be effective in neuropathic and inflammatory pain $(4,5)$. It was also observed that gabapentin possessed central and peripheral antinociceptive effects in experimental pain models (6).

It is well documented that pain is often associated with inflammation. Tissue damage and chemical stimuli in the inflammatory process enhance the release of cytokines. Cytokines are involved in the production of the inflammatory mediators which lead to pain sensation (7). Therefore, we suggest that gabapentin as an antinociceptive effective agent may possess antiinflammatory features.

In this study, we aimed to investigate the effects of gabapentin on experimentally induced inflammation in rats.

\section{Materials and Methods}

\section{Animals}

Male Spraque Dawley rats (200-250g) were used for the study and sheltered in standard conditions of light (12 hours light/dark cycle) and temperature $\left(21 \pm 1{ }^{\circ} \mathrm{C}\right)$. Food and water were available ad libitum. All the experiments were performed with the permission of the Local Ethical Committee of Eskisehir Osmangazi University Medical School for the care and use of laboratory animals (Date and number of the permission: 03.03.2011/192)

\section{Drugs}

Gabapentin (Pfizer) was used at doses of 10 , 30 and $100 \mathrm{mg} / \mathrm{kg}$. In this study, we aimed to investigate the antiinflammatory effect of gabapentin. The doses of gabapentin used in this study were selected considering the effective antinociceptive doses in our previous study (6) and in another study that used formalin test which produces inflammatory pain (8). We used diclofenac sodium (Deva) which is a non steroidal antiinflammatory agent as a positive control to compare its effects with gabapentin $(9,10)$. Diclofenac sodium was used at a dose of $5 \mathrm{mg} / \mathrm{kg}$ (11). Both gabapentin and diclofenac sodium were dissolved in saline.

\section{Study Design}

The animals were randomly divided into 5 groups (8 rats in each group) as below:

\section{Group 1: Control: Saline}

\section{Group 2: Gabapentin 10mg/kg}

Group 3: Gabapentin 30mg/kg

Group 4: Gabapentin 100mg/kg

Group 5: Diclofenac sodium 5mg/kg

Saline, gabapentin $10,30,100 \mathrm{mg} / \mathrm{kg}$ and diclofenac sodium $5 \mathrm{mg} / \mathrm{kg}$ treatments were administered to rats via gavage. The treatments were started on the 4th day of the experimental procedure and lasted for 10 days. Inflammation was formed by formaldehyde injection.

\section{Formation of the Inflammatory Response}

Formaldehyde-induced hind paw edema formation was used to produce local inflammation as in our previous study (12). $0.1 \mathrm{ml}$ of $2 \%$ formaldehyde solution was injected to the plantar surface of the left paw of each rat, regardless of weight, on the 1 st and 3rd days. The distance of the swelling on the left hind paw was measured on the 1st day before formaldehyde injection, on the 4th day before the beginning of drug or saline treatments and on the 14th day (the day after 10 day drug treatment) by using a micrometer. The percent edema and percent edema inhibition was calculated as below and 
expressed as the percentage of the control edema (100\%):

$\%$ edema $=\mathrm{N}^{1} / \mathrm{N}$ x 100

\%edema inhibition $=\mathrm{N}-\mathrm{N}^{1} / \mathrm{N}$ x 100

$\mathrm{N}$ is the edema value (paw diameter measured on the 14th day - initial paw diameter) of the control group.

$\mathrm{N}^{1}$ is the edema value of the experiment group.

\section{Statistical Analysis}

Statistical analysis were performed using SPSS version 15.0 statistical pack software 15.0 (SPSS Inc., Chicago, IL, USA). The data were analyzed statistically with KruskalWallis test. A value of $p<0.05$ was accepted as statistically significant. The results were expressed as median (25\%-75\%).

\section{Results}

\section{Antiinflammatory action}

Our results showed that gabapentin exerted a significant antiinflammatory activity. Gabapentin at all doses (10, 30, $100 \mathrm{mg} / \mathrm{kg})$ decreased \% paw-edema compared to control group $(\mathrm{p}<0.05)$. Diclofenac $(5 \mathrm{mg} / \mathrm{kg})$ also reduced $\%$ paw edema compared to control group $(p<0.05)$. We found that doses of 30 and $100 \mathrm{mg} / \mathrm{kg}$ gabapentin decreased \% pawedema compared to diclofenac $(\mathrm{p}<0.05)$. In accordance with the decrease in $\%$ edema, our results exhibited that gabapentin at all doses significantly increased $\%$ paw-edema inhibition compared to control group. Diclofenac $(5 \mathrm{mg} / \mathrm{kg})$ also increased \% pawedema inhibition compared to control group $(\mathrm{p}<0.05)$. \% paw-edema inhibition was higher at 30 and $100 \mathrm{mg} / \mathrm{kg}$ doses of gabapentin than of diclofenac $(\mathrm{p}<0.05)$. The results are shown in Figure 1.

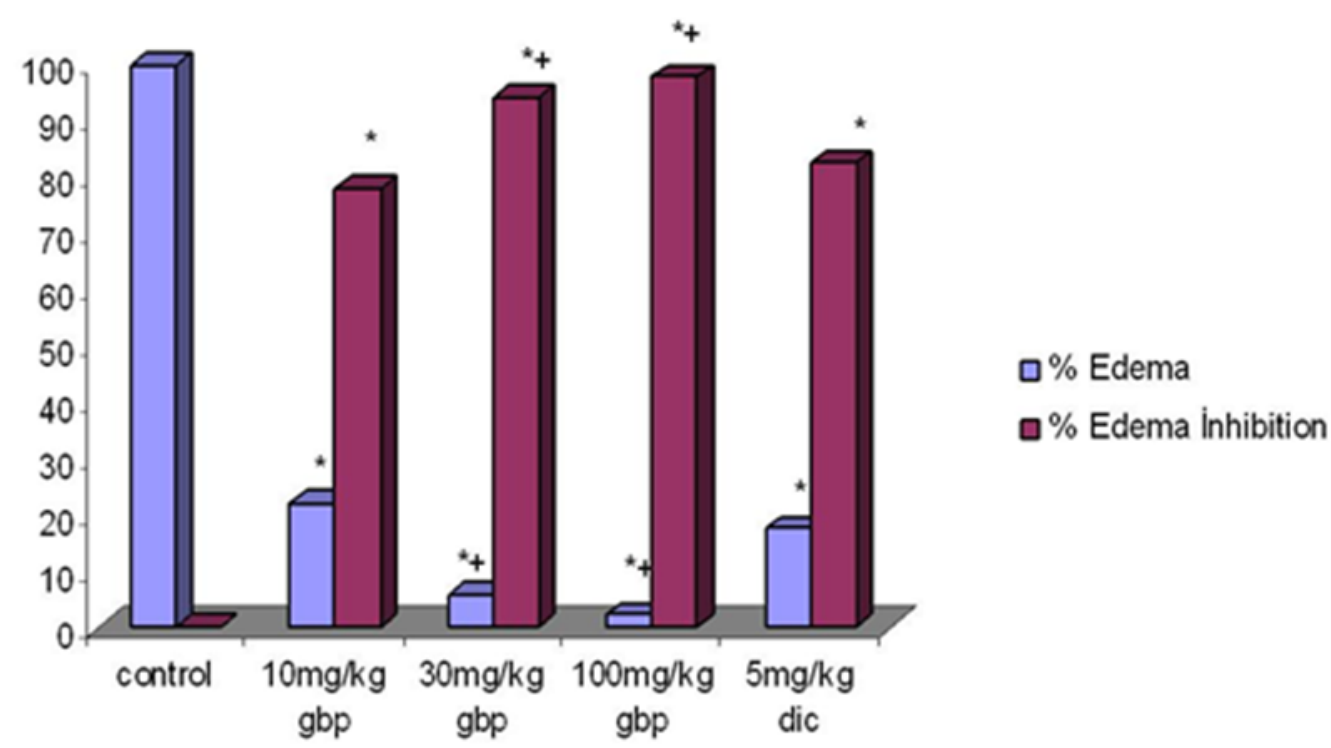

Figure 1. Antiinflammatory effect of gabapentin and diclofenac on \%edema and \%edema inhibition values. Gbp: gabapentin, Dic: diclofenac sodium.

$* \mathrm{P}<0,05$ compared to control, $+\mathrm{P}<0,05$ compared to diclofenac $5 \mathrm{mg} / \mathrm{kg}$. Results are given as median $(\% 25-75)$.

\section{Discussion}

In this study, we found that all doses of gabapentin decreased \% edema, increased \% edema inhibition. The antiinflammatory effect of gabapentin at doses of 30 and $100 \mathrm{mg} / \mathrm{kg}$ was higher than diclofenac.
Houghton et al investigated the effects of $\mathrm{S}$ (+)-3-Isobutylgaba which is a more potent gabapentin analog and its stereoisomer in kaolin and carrageenan induced arthritis models in rats (13). They observed that pretreatment with both of the stereoisomers reduced inflammation and prevented heat hyperalgesia. Although there are differences 
between that and our study in terms of the experimental compound and procedure, these results are partially consistent with the results of our study considering the reduction in the inflammation. Houghton et al. assessed the antiinflammatory and antihyperalgesic effects of S (+)-3-Isobutylgaba and its stereoisomer, administered them spinally and induced inflammation by kaolin and carrageenan injections into the knee joint of the rats while we investigated only the antiinflammatory effects of orally administered gabapentin and used formaldehyde-induced hind paw edema as an inflammation model. However, isobutylgaba is a gabapentin analog and the results can be associated with gabapentin. In another study, Zhang et al assessed gabapentin for antihyperalgesic effect in an arthritis model in rats (14). In that study, the researchers found that gabapentin inhibited arthritis-induced thermal hyperalgesia time and dose dependently. In our study, we did not assess antinociceptive effect of gabapentin but we investigated the antiinflammatory effect. But still, the results of Zhang et al. are indirectly in accordance with our results because it may be suggested that antihyperalgesic effect of gabapentin is related to possible antiinflammatory activity. The evidence to make this suggestion is the data that tissue injury-associated pain typically improves with the resolution of the inflammation. In addition, non steroidal antiinflammatory drugs and interestingly gabapentinoids are effective in inflammatory hyperalgesia (15). In our study, we produced a local inflammation via formaldehyde injection into hind paws of the rats.

\section{Conclusion}

As a conclusion, gabapentin showed antiinflammatory effect. This effect was higher than diclofenac at 30 and $100 \mathrm{mg} / \mathrm{kg}$ doses of gabapentin.

\section{REFERENCES}

1. Eardley, W., \& Toth, C. (2010). An openlabel, non-randomized comparison of venlafaxine and gabapentin as monotherapy or adjuvant therapy in the management of neuropathic pain in patients with peripheral neuropathy. Journal of pain research, 3, 33.

2. Park, H. J., Sandor, K., McQueen, J., Woller, S. A., Svensson, C. I., Corr, M., \& Yaksh, T. L. (2015). The effect of gabapentin and ketorolac on allodynia and conditioned place preference in antibodyinduced inflammation. European Journal of Pain.

3. Yaltho, T. C., \& Ondo, W. G. (2010). The use of gabapentin enacarbil in the treatment of restless legs syndrome. Therapeutic advances in neurological disorders, 3(5), 269-275.

4. Curros-Criado, M., \& Herrero, J. F. (2009). Antinociceptive effects of NCX701 (nitro-paracetamol) in neuropathic rats: enhancement of antinociception by co-administration with gabapentin. British journal of pharmacology, 158(2), 601609.

5. Picazo, A., Castañeda-Hernández, G., \& Ortiz, M. I. (2006). Examination of the interaction between peripheral diclofenac and gabapentin on the $5 \%$ formalin test in rats. Life sciences, 79(24), 2283-2287.

6. Kilic, F. S., Sirmagul, B., Yildirim, E., Oner, S., \& Erol, K. (2012). Antinociceptive effects of gabapentin \& its mechanism of action in experimental animal studies. The Indian journal of medical research, 135(5), 630.

7. Chang, T. N., Deng, J. S., Chang, Y. C., Lee, C. Y., Jung-Chun, L., Lee, M. M., ... \& Huang, G. J. (2012). Ameliorative effects of scopoletin from Crossostephium chinensis against inflammation pain and its mechanisms in mice. Evidence-Based Complementary and Alternative Medicine, 2012.

8. Field, M. J., Oles, R. J., Lewis, A. S., McCleary, S., Hughes, J., \& Singh, L. (1997). Gabapentin (neurontin) and S-(+)3-isobutylgaba represent a novel class of selective antihyperalgesic agents. British journal of pharmacology, 121(8), 15131522.

9. Yewale, S. B., Ganorkar, S. B., Baheti, K. G., \& Shelke, R. U. (2012). Novel 3substituted-1-aryl-5-phenyl-6anilinopyrazolo $[3,4-d]$ pyrimidin-4ones: Docking, synthesis and 
pharmacological evaluation as a potential anti-inflammatory agents. Bioorganic \& medicinal chemistry letters, 22(21), 66166620.

10. Sharma, S., Chattopadhyay, S. K., Yadav, D. K., Khan, F., Mohanty, S., Maurya, A., \& Bawankule, D. U. (2012). QSAR, docking and in vitro studies for antiinflammatory activity of cleomiscosin A methyl ether derivatives. European Journal of Pharmaceutical Sciences, 47(5), 952-964.

11. Ahad, H. A., Padmaja, B. S., Sravanthi, M., Ramyasree, P., \& Kavitha, K. (2012). Phytochemical screening and antiinflammatory actions of Alangium salviifolium root extract. Natural product research, 26(17), 1649-1653.

12. Kilic, F. S., Erol, K., Batu, Ö., Yildirim, E., \& Usluer, G. (2002). The effects of fusidic acid on the inflammatory response in rats. Pharmacological research,45(4), 265-267.

13. Houghton, A. K., Lu, Y., \& Westlund, K. N. (1998). S-(+)-3-isobutylgaba and its stereoisomer reduces the amount of inflammation and hyperalgesia in an acute arthritis model in the rat. Journal of Pharmacology and Experimental Therapeutics, 285(2), 533-538.

14. Zhang, W. S., Xu, H., Xu, B., Sun, S., Deng, X. M., \& Zhang, Y. Q. (2009). Antihyperalgesic effect of systemic dexmedetomidine and gabapentin in a rat model of monoarthritis. Brain research, 1264, 57-66.

15. Xu, Q., \& Yaksh, T. L. (2011). A brief comparison of the pathophysiology of inflammatory versus neuropathic pain. Current opinion in anaesthesiology,24(4), 400. 